\title{
Ny spesialistutdanning for leger - fra sveitserost til kraftkar?
}

DEBATT

\section{MICHAEL BRETTHAUER}

E-post: michael.bretthauer@medisin.uio.no Michael Bretthauer (f. 1969) er professor ved Institutt for helse og samfunn, Det medisinske fakultet, Universitetet i Oslo.

Forfatter har fylt ut ICMJE-skjemaet og oppgir ingen interessekonflikter.

\section{PER OLAV VANDVIK}

Per Olav Vandvik (f. 1968) er førsteamanuensis ved Institutt for helse og samfunn, Det medisinske fakultet, Universitetet i Oslo.

Forfatter har fylt ut ICMJE-skjemaet og oppgir ingen interessekonflikter.

\section{FINN EGIL SKJELDESTAD}

Finn Egil Skjeldestad (f. 1950) er professor ved Institutt for samfunnsmedisin, Det helsevitenskapelige fakultet, Universitetet i Tromsø. Forfatter har fylt ut ICMJE-skjemaet og oppgir ingen interessekonflikter.

\section{JAN C. FRICH}

Jan C. Frich (f. 1970) er professor ved Institutt for helse og samfunn, Det medisinske fakultet, Universitetet i Oslo.

Forfatter har fylt ut ICMJE-skjemaet og oppgir ingen interessekonflikter.

\section{THOMAS DE LANGE}

Thomas de Lange (f. 1960) er (fra 1.10.2017) leder ved Regionalt utdanningssenter i Helse Sør-Øst, Oslo universitetssykehus, og førsteamanuensis ved Institutt for klinisk medisin, Det medisinske fakultet, Universitetet i Oslo.

Forfatter har fylt ut ICMJE-skjemaet og oppgir ingen interessekonflikter.

\section{MAGNUS LøBERG}

Magnus Løberg (f. 1979) er førsteamanuensis ved Institutt for helse og samfunn, Det medisinske fakultet, Universitetet i Oslo.

Forfatter har fylt ut ICMJE-skjemaet og oppgir ingen interessekonflikter.

Kvalitetsforbedring, ledelse og kunnskapshåndtering får en viktig plass i den nye spesialistutdanningen for leger. Styrkingen av legers kompetanse er betimelig, men vil kreve ressurser og kompetente veiledere.

Spesialistutdanningen for leger er omorganisert, og det nye regelverket innebærer omfattende endringer i spesialiseringsløpene for leger (1). Første del av den nye utdanningen for leger i spesialisering (LIS1) starter alt i 2017 og vil erstatte turnustjenesten. 
Andre og tredje del (LIS2 og LIS3) starter etter planen i 2019.

Den nye spesialistutdanningen er ambisiøs og nyskapende når det gjelder å styrke legers systemkompetanse og generelle kompetanse. Etikk og kommunikasjon,

forskningsforståelse og kunnskapshåndtering, kvalitetsforbedring og brukermedvirkning og ledelse og organisering er temaer som utgjør innholdet i de nye «felles

kompetansemoduler» i utdanningen. Styrkingen av slik kompetanse har lenge vært etterlyst av internasjonale fagmiljøer og av norske myndigheter $(2,3)$.

\section{Forhindre konsekvenser av feil}

$\emptyset k t$ vektlegging av kvalitet, ledelse og forbedringsarbeid i helsetjenesten innebærer at vi må utvikle og etablere systemer som kan ivareta integriteten, sikkerheten og kvaliteten $\mathrm{i}$ alle ledd av pasientbehandlingen. Kvalitetsforbedring innebærer blant annet at helsepersonellet og organisasjonene må kunne lære av uønskede hendelser på en systematisk måte.

Sveitserrostmodellen er veletablert innen kvalitetsforbedring og pasientsikkerhetsarbeid (fig 1) (4) og vil inngå som pensum i de nye felles kompetansemodulene. Den skal sørge for kvalitetssystemer som stopper feil før de får uønskede konsekvenser. Leger vil i fremtiden lære å anvende denne modellen og andre grunnleggende prinsipper og metoder for å fremme god og sikker klinisk praksis.

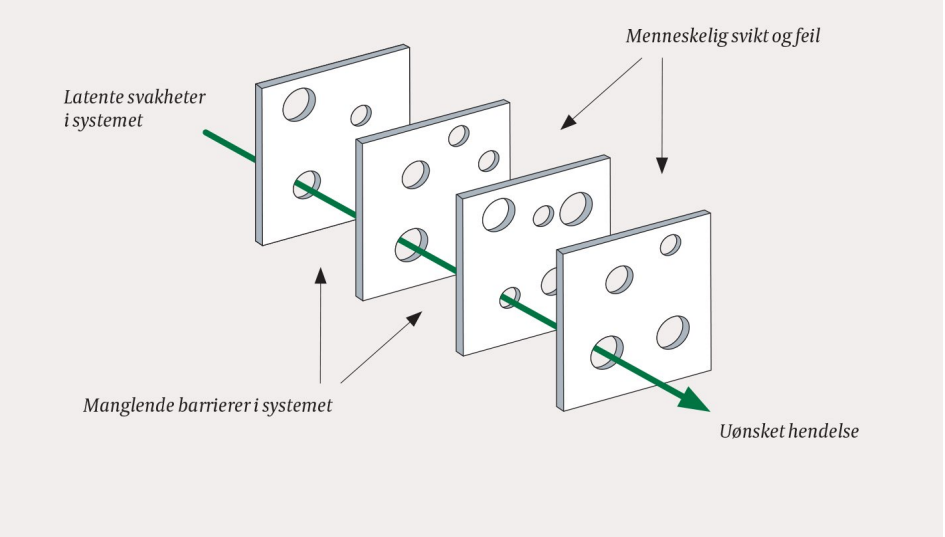

Figur 1 Sveitserostmodellen - en modell for uønskede hendelser i helsevesenet. For at enkeltfeil (venstre side) skal føre til svikt og uønskede hendelser (høyre side) må systemet svikte på mange nivåer (hull i sveitserosten) (4)

\section{Ambisiøse mål}

Alle leger må i fremtiden beherske metoder og strategier for å innhente og bruke gyldig og oppdatert kunnskap innen rammen av kunnskapsbasert praksis (5-7).

Kunnskapshåndtering kombinert med evnen til å kommunisere godt med pasienter om alternativer for diagnostikk og behandling blir en nødvendig del av legers kompetanse. Leger skal være i stand til å lede og forbedre klinisk tjeneste lokalt, der de jobber, på en systematisk og effektiv måte. Dette er områder som hittil er blitt viet lite oppmerksomhet i spesialistutdanningen, men som nå blir obligatorisk for alle spesialiteter og vil strekke seg over hele utdanningsløpet (1).

De siste ti årene er det på medisinstudiet i Oslo gitt undervisning i kvalitet, ledelse og kunnskapshåndtering innen rammen av faget «kunnskapshåndtering, ledelse og kvalitetsforbedring» (KLoK) (4). Ved medisinstudiet i Tromsø er lignende fagområder, kalt profesjonell kompetanse (PROFKOM) og vitenskapelig kompetanse (VITKOM), nylig etablert (3).

Vi ser frem til at spesialistutdanningen skal videreføre og utvide undervisningen i disse 
emnene, og vi er overbevist om at vi vil se et betydelig kompetanseløft som vil gi en bedre helsetjeneste og komme pasienter og brukere til gode. Styrkingen av legers systemkompetanse og generelle kompetanse vil kreve store investeringer ved de nye regionale utdanningssentrene som er under etablering ved de regionale helseforetakene.

Det er lagt opp til at mye av kunnskapstilegningen innen de nye kompetansemodulene skal skje som praksisbasert læring. Det vil derfor også være en stor jobb å gjøre lokalt, på sykehusene og ved legekontorene der legene under utdanning til spesialist har sitt daglige virke.

Helsedirektoratets målbeskrivelser er ambisiøse. Det må lages en plan for å stille ressurser til rådighet og utdanne kompetente veiledere. Ellers vil den nye spesialistutdanningen selv rammes av innsikten som formidles gjennom sveitserostmodellen og ikke bli til Kraftkar, verdens beste ost.

\section{LITTERATUR:}

1. Spesialistutdanning for leger. https://helsedirektoratet.no/autorisasjon-utdanning-og-godkjenning/spesialistgodkjenning/lege/spes ialistutdanning-for-leger (10.7.2017).

2. Frenk J, Chen L, Bhutta ZA et al. Health professionals for a new century: transforming education to strengthen health systems in an interdependent world. Lancet 2010; 376: 1923-58. [PubMed][CrossRef]

3. Frich JC. Medisinsk grunnutdanning - hvordan har universitetene forholdt seg til signaler om nye kompetansebehov. Uniped 2016;39:304-15. [CrossRef]

4. Reason J. Human error: models and management. BMJ 2000; 320: 768 - 70. [PubMed][CrossRef]

5. Frich JC, Gran SF, Vandvik PO et al. Kunnskap, ledelse og kvalitet i studiet. Tidsskr Nor Legeforen 2012; 132: 1768 - 70. [PubMed][CrossRef]

6. Vandvik PO, Bretthauer M, Kongerud IC. Fra kliniske spørsmål til troverdige svar. Tidsskr Nor Legeforen 2013; 133: 1611 - 4. [PubMed][CrossRef]

7. Kongerud IC, Vandvik PO. Arbeidsfiler som læringsverktøy i kunnskapshåndtering. Tidsskr Nor Legeforen 2013; 133: 1587- 90. [PubMed][CrossRef]

Publisert: 18. september 2017. Tidsskr Nor Legeforen. DOI:10.4045/tidsskr.17.0637

Mottatt 28.7.2017, godkjent 24.8.2017.

(C) Tidsskrift for Den norske legeforening 2020. Lastet ned fra tidsskriftet.no 